\title{
Characterization of soybean genotypes for Asian soybean rust reaction
}

\author{
Milena Moura de Araujo $^{1 *}$, and Natal Antonio Vello ${ }^{2}$
}

Received 20 May 2009

Accepted 8 April 2010

\begin{abstract}
Our objective was to characterize soybean experimental lines for Asian soybean rust reaction. In the 2004/2005 growing season, three experiments were conducted with middle-cycle and three with late-cycle genotypes, designed in randomized blocks with four replications. Twelve experimental lines and two cultivars of each cycle were used. In each experiment the plant management differs as follows: three applications of carbendazim or three of flutriafol or without applications. The experimental lines with high yield, low notes to the symptoms and resistance to lodging, were selected and tested again in the 2005/2006 growing season. Genotypes with high severity and yield were considered tolerant to rust and the low severity and high yield ones as moderately resistant. Among the medium-cycle genotypes, there was moderate resistance to rust in one line and tolerance in five. Among the late-cycle genotypes, the six lines showed moderate resistance. The line USP 97-08135 is more tolerant to rust.
\end{abstract}

Key words: Glycine max, Phakopsora pachyrhizi, breeding, genetic resistance.

\section{INTRODUCTION}

In recent years, the Asian soybean rust (ASR), whose causal agent is the biotrophic fungus Phakopsora pachyrhizi (H. Sydow \& P. Sydow) has been a disease of major importance to the soybean-producing countries, affecting even the United States of America in 2004 (Lynch et al. 2006). In Brazil, this disease has caused significant losses, increasing the use of fungicides and reducing the yield.

ASR is considered the most destructive soybean (Glycine max (L.) Merr.) foliar disease (Miles et al. 2003). The main symptom in infected plants is the lesions formation, consisting of pustules reaching 2 to 5 square $\mathrm{mm}$, in which occurs the formation of globular structures called uredias, which produce large numbers of urediniospores. As sporulation proceeds, the leaf tissue around the first uredias acquires a light brown color (tan lesion type - sensitivity) to reddish brown (RB type of injury, reddish brown - resistance) (Bromfield et al. 1980). The ASR is spread by the wind through urediniospores, and may develop rapidly, causing a reduction in leaf area and yield (Bromfield et al. 1980).

The resistant or tolerant cultivars availability is a key component for an ASR integrated control. Genetic resistance of plants to pathogens can be defined as the ability of the host (in this case the plant) to prevent the growth and development of the pathogen (Parlevliet 1997). Parameters such as RB lesions or absence of lesions and symptoms have practical importance for genotypes

\footnotetext{
${ }^{1}$ Universidade de São Paulo (USP), Centro de Energia Nuclear na Agricultura, Av. Centenário, 303, 13.416-000, Piracicaba, SP, Brazil. *E-mail: mmaraujo_07@hotmail.com.

${ }^{2}$ USP, Escola Superior de Agricultura “Luiz de Queiroz”, Departamento de Genética, Av. Pádua Dias, 11, 13.418-900, Piracicaba, SP, Brazil.
} 
differentiation for ASR resistance. RB lesions are formed by a controlled cell death process called hypersensitive response. The cells death limits the fungus development. On the other hand, on susceptible plants, the spores and the fungus enlarge their feeding sites, resulting in a clearer lesion (TAN) on the leaf tissue.

In fact, tolerance can be defined as the plant capacity to resist the pathogen development, without significant reduction in yield or quality of the product (Schafer 1970), which results from the action of polygenes with small and cumulative effects. The intensity of sporulation and periodic severity assessment are important parameters for the classification of genotypes into tolerant or susceptible to ASR. Results presented by Santos et al. (2007), showed the presence of minor genes conferring tolerance to ASR in the Brazilian soybean germplasm. This information can be useful to plant breeders and plant pathologists, to group these genes together in different genotypes, with or without the use of molecular markers.

Five genes for ASR resistance have already been identified, as Rpp1 - PI 200492 (McLean and Byth 1980), Rpp2 - PI 230970 (Bromfield and Hartwig 1980), Rpp3 - PI 462312 (Bromfield and Hartwig 1980, 1983), Rpp4- PI 459025 (Hartwig 1986) and Rpp5 (Parker et al. 1993, Grant et al. 2000, Hayes et al. 2000, Graham et al. 2002, Garcia et al. 2008, Morceli et al. 2008). All these genes confer vertical resistance for only some races of $P$. pachyrhizi and the resistance conferred by these genes has already been broken in most soybean crop regions in Brazil. However, it was shown that the markers linked to gene Rpp5 are useful in the assisted selection, in early stages of plant development and pathogen absence, which streamlines the most promising genotypes selection (Morceli et al. 2008).

Many studies have been conducted with the purpose of identifying the most promising genotypes for use as an ASR resistance source. Koga et al. (2008) used multivariated analysis, Costa et al. (2008) used markers and Santos et al. (2007) evaluated the genotypes partial resistance through epidemiologic and cluster analysis.

This job aims to perform the soybean genotypes characterization for ASR resistance in order to facilitate the work of breeders in the selection of promising genotypes for the use in breeding programs.

\section{MATERIAL AND METHODS}

This study was conducted during the 2004/2005 and 2005/2006 growing seasons in the Department of Genetics of Escola Superior de Agricultura Luiz de Queiroz, Piracicaba, SP. In the 2004/2005 growing season, 24 experimental lines and four soybean commercial cultivars (control) were tested; they were divided into two maturity groups (middle-cycle and late-cycle). In experiments with middle-cycle experimental lines, the cultivars 'BR-16' and 'IAS-5' were used as controls. In experiments with latecycle experimental lines, 'FT-2000' and 'Conquista' were used as controls (Table 1).

Table 1. Middle and late-cycle genotypes used in the 2004/2005 growing season and selected genotypes that composed the experiments of the 2005/2006 growing season

\begin{tabular}{|c|c|c|c|c|c|}
\hline & \multicolumn{3}{|c|}{$\begin{array}{c}\text { 2004/2005 Growing } \\
\text { season }\end{array}$} & & \multirow{2}{*}{$\begin{array}{c}\begin{array}{c}2005 / 2006 \\
\text { Growing season }\end{array} \\
\text { Lines }\end{array}$} \\
\hline & $\begin{array}{l}\text { Middle-Cycle } \\
\text { Lines }\end{array}$ & & $\begin{array}{l}\text { Late-Cycle } \\
\text { Lines }\end{array}$ & & \\
\hline 1 & USP 14-06-34 & 1 & USP 191-101-05 & 1 & USP $14-13-29$ \\
\hline 2 & USP $14-10-45$ & 2 & USP 191-102-02 & 2 & BULK USP 01-28 \\
\hline 3 & USP 14-11-59 & 3 & USP 191-102-03 & 3 & USP 04-18.074 \\
\hline 4 & USP $14-13-29$ & 4 & USP 191-102-12 & 4 & USP 97-08.135 \\
\hline 5 & BULK USP01-28 & 5 & USP 191-103-12 & 5 & USP 191-102-02 \\
\hline 6 & USP 04-18.029 & 6 & USP 191-104-11 & 6 & USP 191-102-03 \\
\hline 7 & USP $04-18.074$ & 7 & USP 191-107-11 & 7 & USP 14-06-34 \\
\hline 8 & USP $04-18.083$ & 8 & USP 191-108-05 & 8 & USP $14-10-45$ \\
\hline 9 & USP 04-18.102 & 9 & USP 02-16.182 & 9 & USP 191-101-05 \\
\hline 10 & USP 97-08.135 & 10 & USP 98-13.035 & 10 & USP 191-103-12 \\
\hline 11 & USP 98-06.015-17 & 11 & USP 98-13.049 & 11 & USP 191-104-11 \\
\hline 12 & USP 98-06.027-05 & 12 & USP 98-13.102 & 12 & USP 191-108-05 \\
\hline \multicolumn{6}{|c|}{ Control Cultivars } \\
\hline 13 & BR-16 & 13 & Conquista & 13 & IAS-5 \\
\hline \multirow[t]{3}{*}{14} & IAS-5 & 14 & FT-2000 & 14 & BR-16 \\
\hline & & & & 15 & FT-2000 \\
\hline & & & & 16 & Conquista \\
\hline
\end{tabular}

The middle-cycle experimental lines comprised 12 lines with cycles between 120 and 140 days and two controls (BR-16 and IAS-5). These lines were selected in the $2003 / 2004$ growing season for yields of $4 \%$ to $221 \%$ higher than the best control ('Conquista', $1755 \mathrm{~kg} \mathrm{ha}^{-1}$ ) in the presence of the disease. The late-cycle experimental lines comprised 12 lines with cycles between 141 and 157 days and yields $87 \%$ to $177 \%$ higher than the best control ('Conquista', $1755 \mathrm{~kg} \mathrm{ha}^{-1}$ ) in the presence of ASR.

Besides the cycle and yield, it was also considered, in the selection of the 24 experimental lines, the presence 
of an ASR-tolerant ancestor in their genealogy, which may have contributed as sources of genes for ASR resistance or tolerance, especially: FT-2 (Godoy and Arias 2003, Yorinori et al. 2003), IAC - PL1 (Godoy and Arias 2003, Yorinori et al. 2003), Tainung 4 and PI 230970 (Taiwan Rpp2) (Bromfield and Hartwig 1980).

To better characterize the genotypes for ASR reaction, the experiments were separated in different cycles, allocated in adjacent areas in the experimental field but separated by borders, in order to avoid the drift of fungicide to another experiment: i) Experiment I: three applications of Impact (flutriafol, $125 \mathrm{~g} \mathrm{~L}^{-1}$, Cheminova) - effective fungicide for late-cycle diseases (DFC) and ASR control; ii) Experiment II: three applications of Derosal (carbendazim, $500 \mathrm{~g} \mathrm{~L}^{-1}$, Bayer) - effective fungicide for the DFC, except ASR control; iii) Experiment III: control - without fungicides application. Fungicides were applied at the recommended dosages on the same dates, with the first application being held at the $\mathrm{R}_{2}$ stage respecting the residual products period (21 days).

Carbendazim and flutriafol treatment were opted for to provide the isolation of the ASR effect, because in the region where the experiments were held, the DFCs frequently occur, which could mask or even bring the results into question. With the adopted method, contrasting experiments carbendazim $x$ flutriafol in yield trials, the ASR reaction effect was isolated, because in the carbendazim experiment only ASR occurs and in the flutriafol no diseases occur. On the other hand, contrasting the flutriafol with the control experiment we would simultaneously have the ASR and DFC effect, therefore the contrast between carbendazim and flutriafol were prioritized.

By the ASR reaction, comparisons were made between the carbendazim and control experiments, because in the flutriafol experiment ASR does not occur, while in the carbendazim experiment only ASR occurs, which makes the assessment more accurate.

The experiments were designed as randomized blocks with four replications of each genotype per experiment. The experimental plots were represented by four rows of $5 \mathrm{~m} \times 0.5 \mathrm{~m}$, and the useful plot consisted of the central rows, eliminating $0.5 \mathrm{~m}$ in each end of the plot, ie, $4 \mathrm{~m}^{2}$.

Evaluations were made about the ASR reaction and yield of genotypes. The ASR reaction was measured using a diagrammatic scale (Amorim 1995), in three weekly evaluations, starting at the $\mathrm{R}_{2}$ stage (first note to the ASR reaction - ASR1; second note to the ASR reaction - ASR2; and third note to the ASR reaction - ASR3), with scores ranging from $1(0.2 \%$ leaf area affected) to 9 (78.5\% or more of leaf area affected). Within this range of 1 to 9 , genotypes with scores between 1-2 were considered resistant; between 3-5 moderately resistant, between 6-7 moderately susceptible and between 8-9 susceptible. We decided to create this large scale, due to its greater efficiency in assessing the ASR reaction of genotypes, because it promotes a better subdivision, allowing an appropriate classification of the genotypes during the phenotypic evaluation. The yield of each genotype was estimated by weighing the useful plot.

The experimental lines selection was conducted under severe infestation of the disease in the field, casting aside the most susceptible genotypes to ASR. To accomplish this selection mainly the yield, the plant ASR reaction, according to the diagrammatic scale, and other traits of interest such as, lodging, plant height and agronomic value was considered. Plants with high yield in the presence of the disease, with low scores for ASR symptoms (below 6.0) and lodging (below 3.0) and high agronomic value (above 3.5) were selected for 2005/2006 growing season (Table 1 ).

In the 2005/2006 experiment the same design, fungicides (each fungicide was considered a separate experiment) and plot size of the previous year was used, however, 12 experimental lines were selected among the 24 tested in 2004/2005 growing season to compose these experiments. There was not a division of the experiments in two distinct cycles (middle and late), because the selected lines were in the range of transition between these two cycles, then it was not necessary to allocate the genotypes in different experiments.

It was extremely important to conduct this experiment to verify if the genotypes performance was consistent from one year to another or if there would be changes in the ASR response.

We performed the analysis of variance for the traits: yield and ASR reaction (Tables 2 and 3). For this last trait there was not a normal distribution of data, requiring the verification of the homogeneity of variances. Through the test Fmax, it was found that there was homogeneity of variances for all assessments of ASR reaction, allowing the analysis of variance, since the $F$ test is robust to the lack of normality in cases where there is homogeneity of variances.

With the detection of significant differences between genotypes, the Scott-Knott (SK) comparison test of 
MM Araújo and NA Vello

Table 2. Analysis of variance of Carbendazim, Flutriafol and Control experiments to the yield for the middle and late-cycle genotypes in the 2004/2005 growing season and for the selected genotypes of the 2005/2006 growing season

\begin{tabular}{|c|c|c|c|c|c|c|}
\hline \multirow[b]{3}{*}{ Source of variation } & \multicolumn{4}{|c|}{$2004 / 2005$ growing season } & \multirow{2}{*}{\multicolumn{2}{|c|}{$\begin{array}{c}\text { 2005/2006 growing } \\
\text { season }\end{array}$}} \\
\hline & \multicolumn{2}{|c|}{ Middle-Cycle } & \multicolumn{2}{|c|}{ Late-Cycle } & & \\
\hline & df & $\mathbf{F}$ & df & $\mathbf{F}$ & df & $\mathbf{F}$ \\
\hline Blocks & 9 & & 9 & & 9 & \\
\hline Experiments (E) & 2 & $17.95 * *$ & 2 & $4.22 * *$ & 2 & $146.55^{* *}$ \\
\hline Controls (C) & 1 & 1.23 & 1 & 0.29 & 3 & $21.73 * *$ \\
\hline $\mathrm{C} \times \mathrm{E}$ & 2 & 0.04 & 2 & 0.22 & 6 & 1.99 \\
\hline Genotypes/E & 33 & $3.52 * *$ & 33 & $4.44 * *$ & 33 & $4.89 * *$ \\
\hline Lines (L) & 11 & $7.96 * *$ & 11 & $9.12 * *$ & 11 & $11.71 * *$ \\
\hline $\mathrm{L} \times \mathrm{E}$ & 22 & $1.76^{*}$ & 22 & $2.13 * *$ & 22 & 1.11 \\
\hline$(\mathrm{C}$ vs L $) / \mathrm{E}$ & 3 & $4.20 * *$ & 3 & 2.35 & 3 & $6.35^{* *}$ \\
\hline Error & 117 & & 117 & & 135 & \\
\hline Total & 167 & & 167 & & 191 & \\
\hline
\end{tabular}

* Significant at $5 \%$ and ** significant at $1 \%$ by $\mathrm{F}$ test.

Table 3. Summary of the joint analysis of variance (F values) of Carbendazim and Control experiments for ASR notes (ASR1, ASR2 and ASR3), for the middle and late-cycle genotypes in the 2004/2005 growing season and of the selected genotypes that composed the experiments of the 2005/2006 growing season

\begin{tabular}{|c|c|c|c|c|c|c|c|c|c|c|c|}
\hline \multirow{3}{*}{ Source of Variation } & \multicolumn{7}{|c|}{ 2004/2005 Growing Season } & \multicolumn{4}{|c|}{ 2005/2006 Growing Season } \\
\hline & \multicolumn{4}{|c|}{ F (Middle-Cycle) } & \multicolumn{3}{|c|}{ F (Late-Cycle) } & \multirow[b]{2}{*}{ df } & \multirow[b]{2}{*}{ ASR1 } & \multirow[b]{2}{*}{ ASR2 } & \multirow[b]{2}{*}{ ASR3 } \\
\hline & df & ASR1 & ASR2 & ASR3 & ASR1 & ASR2 & ASR3 & & & & \\
\hline Blocks & 6 & & & & & & & 6 & & & \\
\hline Experiments (E) & 1 & $21.82 * *$ & $18.78 * *$ & $8.64 * *$ & $45.63 * *$ & $6.20 *$ & $5.93 *$ & 1 & 1.44 & 0.80 & 0.43 \\
\hline Controls (C) & 1 & $6.83^{*}$ & 2.62 & 0.32 & 1.04 & 1.16 & $6.47 *$ & 3 & $5.12 * *$ & $2.95^{*}$ & 0.25 \\
\hline $\mathrm{C} \times \mathrm{E}$ & 1 & 0.06 & 1.88 & 0.04 & 0.26 & 0.70 & 0.03 & 3 & $3.93^{*}$ & 2.37 & 0.07 \\
\hline Genotypes/E & 22 & $5.45^{* *}$ & $7.48 * *$ & $6.22 * *$ & 0.54 & 1.40 & 1.14 & 22 & $2.91 * *$ & $3.14 * *$ & $2.38 * *$ \\
\hline Lines $(\mathrm{L})$ & 11 & $10.79^{* *}$ & $12.66^{* *}$ & $9.20 * *$ & 0.50 & $2.07^{*}$ & 1.41 & 11 & $5.33^{* *}$ & $5.72 * *$ & $2.86^{* *}$ \\
\hline $\mathrm{L} \times \mathrm{E}$ & 11 & 1.28 & 1.63 & 1.69 & 0.53 & 0.49 & 0.66 & 11 & 0.63 & 0.46 & 1.06 \\
\hline$(\mathrm{C}$ vs $\mathrm{L}) / \mathrm{E}$ & 2 & $20.13^{* *}$ & $13.33 * *$ & $8.29 * *$ & $4.08^{*}$ & $8.01 * *$ & $5.12 * *$ & 2 & $18.42 * *$ & $14.82 * *$ & 2.34 \\
\hline Error & 78 & & & & & & & 90 & & & \\
\hline Total & 111 & & & & & & & 127 & & & \\
\hline
\end{tabular}

* Significant at $5 \%$ and $* *$ significant at $1 \%$ by $\mathrm{F}$ test.

averages at the significance level of $5 \%$ was accomplished because this test is very efficient in the averages grouping (Bhering et al. 2008).

\section{RESULTS AND DISCUSSION}

The yield obtained in the experiments followed the region's pattern yield. As was expected, the average experimental lines yield in the flutriafol experiment was higher than in the carbendazim and control experiments in middle-cycle lines of the 2004/2005 and the lines of the 2005/2006 growing season, since this fungicide promoted the ASR and DFC efficient control (Table 4).

However, in the late-cycle genotypes of the 2004/ 2005 growing season, the yield in the flutriafol experiment did not differ statistically at 5\% probability of the control experiment, and the yield in the carbendazim experiment was lower (Table 4). This is not a normal condition, as indicated by the data of the 2005/2006 growing season. Thus, physiological reactions of incompatibility between fungicides and the different genotypes may have been more significant than the effects of the fungicides in disease control in the 2005/2006 growing season.

The main characteristics of the ASR moderately resistant genotypes is the occurrence of few symptoms (notes below 6.0) and high yield, which mainly takes place in the middle-cycle genotype USP 97-08.135 (2004/2005), which remained moderately resistant to ASR over the three assessments of severity, besides presenting a lower reduction in yield. The late-cycle lines that presented ASR 
Characterization of soybean genotypes for Asian soybean rust reaction

Table 4. Scott-Knott test to detect differences in yield and in experiments, between the middle and late-cycle genotypes in the Flutriafol (F), Carbendazim (Ca) and Control (C) experiments in the 2004/2005 growing season and between selected genotypes that composed the experiments of the $2005 / 2006$ growing season

\begin{tabular}{|c|c|c|c|c|c|c|c|c|c|c|c|}
\hline \multicolumn{8}{|c|}{ 2004/2005 Growing Season } & \multicolumn{4}{|c|}{ 2005/2006 Growing Season } \\
\hline \multicolumn{4}{|c|}{ Middle-Cycle } & \multicolumn{4}{|c|}{ Late-Cycle } & \multirow[b]{2}{*}{ Genotypes } & \multirow[b]{2}{*}{$\mathbf{F}$} & \multirow[b]{2}{*}{$\mathbf{C a}$} & \multirow[b]{2}{*}{$\mathbf{C}$} \\
\hline Genotypes & $\mathbf{F}$ & $\mathrm{Ca}$ & C & Genotypes & $\mathbf{F}$ & $\mathrm{Ca}$ & $\mathrm{C}$ & & & & \\
\hline USP 04-18.074 & $2.480 \mathrm{Aa}$ & $2.965 \mathrm{Aa}$ & $2.305 \mathrm{Aa}$ & USP $191-103-12$ & $2.016 \mathrm{Aa}$ & $2.488 \mathrm{Aa}$ & $2.284 \mathrm{Aa}$ & BR-16 & $2.654 \mathrm{Aa}$ & $1.810 \mathrm{Ba}$ & $1.759 \mathrm{Ba}$ \\
\hline BULK USP 01-28 & $2.470 \mathrm{Aa}$ & $2.636 \mathrm{Aa}$ & $1.840 \mathrm{Ab}$ & USP $191-102-03$ & $1.981 \mathrm{Ba}$ & $1.876 \mathrm{Ba}$ & $2.662 \mathrm{Aa}$ & IAS-5 & $2.471 \mathrm{Aa}$ & $1.698 \mathrm{Aa}$ & $2.130 \mathrm{Aa}$ \\
\hline USP 97-08.135 & $2.268 \mathrm{Aa}$ & $2.524 \mathrm{Aa}$ & $2.085 \mathrm{Aa}$ & USP 98-13.049 & $1.131 \mathrm{Ab}$ & $1.822 \mathrm{Aa}$ & $1.415 \mathrm{Ab}$ & USP 04-18.074 & $2.600 \mathrm{Aa}$ & $1.684 \mathrm{Ba}$ & $1.865 \mathrm{Ba}$ \\
\hline USP 04-18.102 & $2.091 \mathrm{Aa}$ & $2.446 \mathrm{Aa}$ & $2.114 \mathrm{Aa}$ & USP 191-104-11 & $2.009 \mathrm{Aa}$ & $1.790 \mathrm{Aa}$ & $1.824 \mathrm{Ab}$ & BULK USP 01-28 & $2.559 \mathrm{Aa}$ & $1.650 \mathrm{Ba}$ & $1.552 \mathrm{Ba}$ \\
\hline USP 04-18.029 & $2.479 \mathrm{Aa}$ & $2.416 \mathrm{Aa}$ & $2.358 \mathrm{Aa}$ & Conquista & $1.988 \mathrm{Aa}$ & $1.642 \mathrm{Aa}$ & $1.634 \mathrm{Ab}$ & USP 97-08.135 & $1.950 \mathrm{Ab}$ & $1.569 \mathrm{Aa}$ & $1.876 \mathrm{Aa}$ \\
\hline IAS-5 & $2.796 \mathrm{Aa}$ & $2.116 \mathrm{Ab}$ & $2.306 \mathrm{Aa}$ & USP $191-108-05$ & $1.442 \mathrm{Ab}$ & $1.615 \mathrm{Aa}$ & $1.596 \mathrm{Ab}$ & USP191-103-12 & $2.418 \mathrm{Aa}$ & $1.538 \mathrm{Aa}$ & $1.749 \mathrm{Aa}$ \\
\hline USP 14-11-59 & $2.579 \mathrm{Aa}$ & $2.034 \mathrm{Bb}$ & $1.744 \mathrm{Bb}$ & FT-2000 & $2.164 \mathrm{Aa}$ & $1.580 \mathrm{Aa}$ & $1.785 \mathrm{Ab}$ & USP 191-102-02 & $1.910 \mathrm{Ab}$ & $1.310 \mathrm{Bb}$ & $1.260 \mathrm{Bb}$ \\
\hline USP 04-18.083 & $2.366 \mathrm{Aa}$ & $1.999 \mathrm{Ab}$ & $1.688 \mathrm{Ab}$ & USP 02-16.182 & $2.229 \mathrm{Ba}$ & $1.539 \mathrm{Ca}$ & $2.645 \mathrm{Aa}$ & USP 191-101-05 & $1.845 \mathrm{Ab}$ & $1.308 \mathrm{Ab}$ & $1.239 \mathrm{Ab}$ \\
\hline BR-16 & $2.629 \mathrm{Aa}$ & $1.969 \mathrm{Bb}$ & $2.051 \mathrm{Ba}$ & USP 191-107-11 & $2.009 \mathrm{Aa}$ & $1.462 \mathrm{Aa}$ & $1.564 \mathrm{Ab}$ & USP $14-10-45$ & $2.182 \mathrm{Ab}$ & $1.242 \mathrm{Bb}$ & $1.356 \mathrm{Bb}$ \\
\hline USP $14-10-45$ & $2.394 \mathrm{Aa}$ & $1.794 \mathrm{Ab}$ & $1.332 \mathrm{Ac}$ & USP $191-102-02$ & $1.995 \mathrm{Aa}$ & $1.430 \mathrm{Ba}$ & $1.652 \mathrm{Bb}$ & FT-2000 & $2.261 \mathrm{Aa}$ & $1.118 \mathrm{Bb}$ & $1.260 \mathrm{Bb}$ \\
\hline USP 14-13-29 & $2.135 \mathrm{Aa}$ & $1.702 \mathrm{Ab}$ & $1.941 \mathrm{Aa}$ & USP 191-101-05 & $1.856 \mathrm{Aa}$ & $1.414 \mathrm{Aa}$ & $1.736 \mathrm{Ab}$ & USP 14-06-34 & $2.118 \mathrm{Ab}$ & $1.090 \mathrm{Bb}$ & $1.049 \mathrm{Bb}$ \\
\hline USP 14-06-34 & $1.788 \mathrm{Aa}$ & $1.610 \mathrm{Ab}$ & $1.664 \mathrm{Ab}$ & USP $191-102-12$ & $1.714 \mathrm{Aa}$ & $1.390 \mathrm{Aa}$ & $1.480 \mathrm{Ab}$ & USP 191-102-03 & $1.783 \mathrm{Ab}$ & $1.085 \mathrm{Ab}$ & $1.239 \mathrm{Ab}$ \\
\hline USP 98-06.015-17 & $2.285 \mathrm{Aa}$ & $1.519 \mathrm{Bb}$ & $1.689 \mathrm{Bb}$ & USP 98-13.102 & $1.190 \mathrm{Bb}$ & $1.320 \mathrm{Ba}$ & $1.848 \mathrm{Ab}$ & USP 191-104-11 & $2.002 \mathrm{Ab}$ & $1.058 \mathrm{Bb}$ & $905 \mathrm{Bc}$ \\
\hline \multirow[t]{3}{*}{ USP 98-06.027-05 } & $2.002 \mathrm{Aa}$ & $1.341 \mathrm{Ab}$ & $1.001 \mathrm{Ac}$ & USP 98-13.035 & $816 \mathrm{Bb}$ & $1.075 \mathrm{Aa}$ & $1.334 \mathrm{Ab}$ & USP 14-13-29 & $1.518 \mathrm{Ab}$ & $1.058 \mathrm{Ab}$ & $1.085 \mathrm{Ab}$ \\
\hline & & & & & & & & Conquista & $2.131 \mathrm{Ab}$ & $858 \mathrm{Bc}$ & $808 \mathrm{Bc}$ \\
\hline & & & & & & & & USP 19110805 & $1678 \mathrm{Ab}$ & $810 \mathrm{Bc}$ & $656 \mathrm{Bc}$ \\
\hline Means & $2.340 \mathrm{~A}$ & $2.077 \mathrm{~B}$ & $1.866 \mathrm{C}$ & & $1.746 \mathrm{~A}$ & $1.603 \mathrm{~B}$ & 1.818 & & $2.130 \mathrm{~A}$ & $1.305 \mathrm{~B}$ & $1.362 \mathrm{~B}$ \\
\hline
\end{tabular}

Averages followed by the same letter, uppercase in lines and lowercase in columns, do not differ at $5 \%$ probability by Scott-Knott test.

moderate resistance were USP 191-102-03, USP 191-10312, USP 191-108-05, USP 98-13035, USP 98-13049 and USP 98-13.102 (2004/2005) (Tables 4 and 5).

The tolerance is characterized as the genotype ability to keep the yield, despite the plant showing severe symptoms of disease (Schafer 1970), the tolerant genotypes can be characterized for showing the yield in the flutriafol experiment approximately equal to the carbendazim experiment, and at the same time, high notes to ASR, that is, despite the tolerant plants perhaps

Table 5. Scott-Knott test for the ASR notes (ASR1, ASR2 and ASR3) in Carbendazim (Ca) and control (C) experiments for the genotypes of the 2004/2005 growing season and for the selected genotypes of the 2005/2006 growing season

\begin{tabular}{|c|c|c|c|c|c|c|c|c|c|c|c|c|c|}
\hline \multicolumn{7}{|c|}{ 2004/2005 Growing Season } & \multicolumn{7}{|c|}{$2005 / 2006$ Growing Season } \\
\hline \multicolumn{14}{|c|}{ Middle-Cycle } \\
\hline & \multicolumn{3}{|c|}{$\mathrm{Ca}$} & \multicolumn{3}{|c|}{$\mathrm{C}$} & \multicolumn{4}{|c|}{$\mathrm{Ca}$} & \multicolumn{3}{|c|}{$\mathrm{C}$} \\
\hline Genotypes & ASR1 & ASR2 & ASR3 & ASR1 & ASR2 & ASR3 & Genotypes & ASR1 & ASR2 & ASR3 & ASR1 & ASR2 & ASR3 \\
\hline $\mathrm{BR}-16$ & $5.5 \mathrm{a}$ & $7.9 \mathrm{a}$ & $9.0 \mathrm{a}$ & $6.5 \mathrm{a}$ & $7.4 \mathrm{a}$ & $9.0 \mathrm{a}$ & BR-16 & $3.0 \mathrm{a}$ & $7.0 \mathrm{a}$ & $9.0 \mathrm{a}$ & $3.0 \mathrm{a}$ & $7.5 \mathrm{a}$ & $9.0 \mathrm{a}$ \\
\hline USP 04-18.029 & $5.2 \mathrm{a}$ & $6.8 \mathrm{a}$ & $9.0 \mathrm{a}$ & $5.0 \mathrm{~b}$ & $6.4 \mathrm{~b}$ & $9.0 \mathrm{a}$ & IAS-5 & $2.5 \mathrm{a}$ & $7.0 \mathrm{a}$ & $9.0 \mathrm{a}$ & $2.0 \mathrm{~b}$ & $5.2 \mathrm{~b}$ & $9.0 \mathrm{a}$ \\
\hline IAS-5 & $4.2 \mathrm{~b}$ & $6.4 \mathrm{a}$ & $8.5 \mathrm{a}$ & $5.0 \mathrm{~b}$ & $7.2 \mathrm{a}$ & $8.8 \mathrm{a}$ & BULK USP 01-28 & $2.5 \mathrm{a}$ & $6.5 \mathrm{a}$ & $9.0 \mathrm{a}$ & $2.2 \mathrm{a}$ & $6.0 \mathrm{a}$ & $9.0 \mathrm{a}$ \\
\hline USP 04-18.074 & $4.2 \mathrm{~b}$ & $7.2 \mathrm{a}$ & $9.0 \mathrm{a}$ & $5.2 \mathrm{~b}$ & $8.1 \mathrm{a}$ & $9.0 \mathrm{a}$ & USP 04-18.074 & $2.2 \mathrm{a}$ & $6.5 \mathrm{a}$ & $9.0 \mathrm{a}$ & $3.0 \mathrm{a}$ & $7.2 \mathrm{a}$ & $8.5 \mathrm{a}$ \\
\hline BULK USP 01-28 & $4.2 \mathrm{~b}$ & $6.8 \mathrm{a}$ & $9.0 \mathrm{a}$ & $5.2 \mathrm{~b}$ & $7.1 \mathrm{a}$ & $9.0 \mathrm{a}$ & USP 191-102-02 & $2.0 \mathrm{~b}$ & $5.0 \mathrm{~b}$ & $9.0 \mathrm{a}$ & $2.0 \mathrm{~b}$ & $5.5 \mathrm{a}$ & $8.0 \mathrm{a}$ \\
\hline USP 04-18.083 & $4.0 \mathrm{c}$ & $6.5 \mathrm{a}$ & $9.0 \mathrm{a}$ & $5.0 \mathrm{~b}$ & $7.6 \mathrm{a}$ & $9.0 \mathrm{a}$ & Conquista & $1.8 \mathrm{~b}$ & $5.0 \mathrm{~b}$ & $8.8 \mathrm{a}$ & $2.0 \mathrm{~b}$ & $5.8 \mathrm{a}$ & $8.8 \mathrm{a}$ \\
\hline USP $14-11-59$ & $3.8 \mathrm{c}$ & $7.5 \mathrm{a}$ & $8.2 \mathrm{a}$ & $5.0 \mathrm{~b}$ & $7.5 \mathrm{a}$ & $9.0 \mathrm{a}$ & FT-2000 & $1.8 \mathrm{~b}$ & $5.2 \mathrm{~b}$ & $9.0 \mathrm{a}$ & $2.8 \mathrm{a}$ & $6.8 \mathrm{a}$ & $8.8 \mathrm{a}$ \\
\hline USP 04-18.102 & $3.0 \mathrm{~d}$ & $5.0 \mathrm{~b}$ & $5.5 \mathrm{~b}$ & $4.8 \mathrm{~b}$ & $6.0 \mathrm{~b}$ & $9.0 \mathrm{a}$ & USP 191-101-05 & $1.8 \mathrm{~b}$ & $5.2 \mathrm{~b}$ & $8.8 \mathrm{a}$ & $1.8 \mathrm{~b}$ & $5.0 \mathrm{~b}$ & $9.0 \mathrm{a}$ \\
\hline USP 98-06.015-17 & $2.2 \mathrm{e}$ & $3.6 \mathrm{~b}$ & $5.1 \mathrm{~b}$ & $2.0 \mathrm{f}$ & $4.5 \mathrm{c}$ & $5.5 \mathrm{c}$ & USP 14-06-34 & $1.8 \mathrm{~b}$ & $5.0 \mathrm{~b}$ & $8.2 \mathrm{a}$ & $2.0 \mathrm{~b}$ & $5.8 \mathrm{a}$ & $9.0 \mathrm{a}$ \\
\hline USP 97-08.135 & $2.0 \mathrm{e}$ & $4.1 \mathrm{~b}$ & $5.0 \mathrm{~b}$ & $3.5 \mathrm{~d}$ & $6.6 \mathrm{~b}$ & $7.5 \mathrm{~b}$ & USP 191-104-11 & $1.5 \mathrm{~b}$ & $4.8 \mathrm{~b}$ & $8.8 \mathrm{a}$ & $1.5 \mathrm{~b}$ & $4.5 \mathrm{~b}$ & $9.0 \mathrm{a}$ \\
\hline USP $14-13-29$ & $2.0 \mathrm{e}$ & $5.6 \mathrm{a}$ & $6.5 \mathrm{~b}$ & $2.2 \mathrm{f}$ & $6.1 \mathrm{~b}$ & $7.2 \mathrm{~b}$ & USP $14-10-45$ & $1.5 \mathrm{~b}$ & $4.2 \mathrm{~b}$ & $8.0 \mathrm{~b}$ & $1.2 \mathrm{~b}$ & $3.2 \mathrm{~b}$ & $8.8 \mathrm{a}$ \\
\hline USP $14-10-45$ & $2.0 \mathrm{e}$ & $3.9 \mathrm{~b}$ & $5.5 \mathrm{~b}$ & $2.5 \mathrm{f}$ & $4.0 \mathrm{c}$ & $4.2 \mathrm{c}$ & USP 97-08.135 & $1.5 \mathrm{~b}$ & $4.2 \mathrm{~b}$ & $8.5 \mathrm{a}$ & $1.8 \mathrm{~b}$ & $4.5 \mathrm{~b}$ & $8.5 \mathrm{a}$ \\
\hline USP 14-06-34 & $2.0 \mathrm{e}$ & $3.2 \mathrm{~b}$ & $5.2 \mathrm{~b}$ & $3.0 \mathrm{e}$ & $5.9 \mathrm{~b}$ & $7.0 \mathrm{~b}$ & USP 191-103-12 & $1.2 \mathrm{~b}$ & $3.8 \mathrm{~b}$ & $9.0 \mathrm{a}$ & $1.5 \mathrm{~b}$ & $4.2 \mathrm{~b}$ & $8.8 \mathrm{a}$ \\
\hline \multirow[t]{3}{*}{ USP 98-06.027-05 } & $1.8 \mathrm{e}$ & $4.6 \mathrm{~b}$ & $6.5 \mathrm{~b}$ & $4.3 \mathrm{c}$ & $6.1 \mathrm{~b}$ & $8.2 \mathrm{a}$ & USP 14-13-29 & $1.2 \mathrm{~b}$ & $4.2 \mathrm{~b}$ & $8.5 \mathrm{a}$ & $1.2 \mathrm{~b}$ & $4.2 \mathrm{~b}$ & $9.0 \mathrm{a}$ \\
\hline & & & & & & & USP 191-108-05 & $1.0 \mathrm{~b}$ & $2.8 \mathrm{~b}$ & $7.0 \mathrm{c}$ & $1.0 \mathrm{~b}$ & $3.0 \mathrm{~b}$ & $7.8 \mathrm{a}$ \\
\hline & & & & & & & USP 191-102-03 & $1.0 \mathrm{~b}$ & $3.8 \mathrm{~b}$ & $9.0 \mathrm{a}$ & $1.8 \mathrm{~b}$ & $5.0 \mathrm{~b}$ & $9.0 \mathrm{a}$ \\
\hline
\end{tabular}

In each column, averages followed by same letter do not differ at 5\% probability by Scott-Knott test. 
presenting many disease symptoms, they have no significant drop in yield. On the other hand, the genotypes with higher yields in the flutriafol experiment than in the carbendazim and low notes to ASR reaction can be classified as intolerant because although they do not display many symptoms they have a decrease in the performance. But the genotypes, which have the yield in the flutriafol experiment higher than in carbendazim, which decreases yield in the presence of the disease, and have high notes, they can be characterized as susceptible.

Given the above, tolerance to ASR was verified, especially in the middle-cycle experimental line USP 0418.029 (2004/2005). In that, among the late-cycle genotypes none were ASR tolerant.

In the 2005/2006 growing season there was no moderate resistance in the genotypes tested; however, the genotype USP 191-108-05 was closer to the tolerant behavior (Table 5). In this light, the best genotypes for a breeding program aimed at getting ASR tolerance and productive genotypes are: USP 04-18029 and USP 191108-05. These genotypes can be used in recurrent selection cycles for the introgression of minor genes that provide ASR tolerance.

The late-cycle genotypes that showed ASR moderate resistance in the 2004/2005 growing season (USP 191-102-03, USP 191-103-12, USP 191-108-05, USP 98-13035, USP 98-13049 and USP 98-13102), could be used by farmers because they have few symptoms and high yield, however, they present a higher risk of having their resistance broken in a short term.

\section{ACKNOWLEDGMENTS}

he authors wish to thank CNPq and CAPES for the Master's grant to the first author and for the research assistance.

\section{Caracterização de linhagens de soja quanto à reação à ferrugem asiática}

RESUMO - O objetivo deste trabalho foi caracterizar linhagens de soja quanto à reação à ferrugem asiática. No ano agrícola 2004/2005 conduziu-se três experimentos com genótipos de ciclo médio e três com tardios, delineados em blocos casualizados, com quatro repetições. Utilizou-se 12 linhagens e duas cultivares, para cada ciclo. Em cada experimento, com plantas de mesmo ciclo, o manejo fitossanitário diferiu como segue: três aplicações de carbendazim ou três de flutriafol ou sem fungicida. As linhagens com elevado rendimento, com notas baixas para os sintomas e resistentes ao acamamento, foram selecionadas e novamente testadas em 2005/2006. Genótipos com elevada severidade e rendimento foram considerados tolerantes, os com baixa severidade e elevado rendimento, como moderadamente resistentes. Entre os genótipos com ciclo médio, observou-se resistência moderada em uma linhagem e tolerância em cinco. Entre os de ciclo tardio, as seis linhagens apresentaram resistência moderada. A linhagem USP 97-08135 apresenta maior tolerância à ferrugem.

Palavras-chave: Glycine max, Phakopsora pachyrhizi, melhoramento genético, resistência genética.

\section{REFERENCES}

Amorim L (1995) Avaliação de doenças. In Bergamim Filho A, Kimati $\mathrm{H}$ and Amorim L (eds.) Manual de fitopatologia. Agronômica Ceres, São Paulo, p. 647-670.

Bhering LL, Cruz CD, Vasconcelos ES, Ferreira A and Resende Júnior MFR (2008) Alternative methodology for Scott-Knott test. Crop Breeding and Applied Biotechnology 8: 9-16.

Bromfield KR, Melching JS and Kingsolver CH (1980) Virulence and aggressiveness of Phakopsora pachyrhizi isolates causing soybean rust. Phytopathology 70: 17-21.
Bromfield KR and Hartwig EE (1980) Resistance to soybean rust and mode of inheritance. Crop Science 20: 254-255.

Costa MM, Unêda-Trevisoli SH, Pinheiro JB, Kiihl RAS, Calvo EB and Di Mauro AO (2008) Marcadores RAPD para detecção de resistência à ferrugem-asiática-da-soja. Pesquisa Agropecuária Brasileira 43: 1733-1739.

Garcia A, Calvo ES, Kiihl RAS, Harada A, Hiromoto DM and Vieira LGE (2008) Molecular mapping of soybean rust (Phakopsora pachyrhizi) resistance genes: discovery of a novel locus and alleles. Theoretical and Applied Genetics 117: 545-553. 
Godoy CV and Arias CAA (2003) Resistência quebrada. Cultivar 5: $28-29$.

Graham MA, Marek LF and Shoemaker RC (2002) Organization, expression and evolution of a disease resistance gene cluster in soybean. Genetics 162: 1961-1977.

Grant D, Cregan P and Shoemaker RC (2000) Genome organization in dicots: Genome duplication in Arabidopsis and synteny between soybean and Arabidopsis. Proceedings of the National Academy of Sciences 97: 4168-4173.

Hartwig EE (1986) Identification of a fourth major gene conferring resistance to soybean rust. Crop Science 26: 1135-1136.

Hayes AJ, Yue YG and Saghai Maroof MA (2000) Expression of two soybean resistance gene candidates shows divergence of paralogous single-copy genes. Theoretical and Applied Genetics 101: 789-795.

Koga LJ, Canteri MG, Calvo ES, Unfried JR, Garcia A, Harada A and Kiihl RAS (2008) Análise multivariada dos componentes da resistência à ferrugem-asiática em genótipos de soja. Pesquisa Agropecuária Brasileira 43: 1277-1286.

Lynch TN, Marois JJ, Wright DL, Harmon PF, Harmon CL, Miles MR and Hartman GL (2006) First report of soybean rust caused by Phakopsora pachyrhizi on Phaseolus species in the United States. Plant Disease 90: 970.

McLean RJ and Byth DE (1980) Inheritance of resistance to rust (Phakopsora pachyrhizi) in soybeans. Australian Journal of Agricultural Research 31: 951-956.
Miles MR, Frederick RD and Hartman G (2003) Soybean rust: is the U.S. soybean crop at risk? In APSNET Feature. American Phytopathological Society. Available on http://www.apsnet.org/ online/feature/rust/ Access on 11 July 2007.

Morceli TGS, Trevisoli SHU, Junior AAM, Kiihl RAS, Calvo ES, Di Mauro AO and Garcia A (2008) Identificação e validação de marcadores microssatélites ligados ao gene Rpp5 de resistência à ferrugem-asiática-da-soja. Pesquisa Agropecuária Brasileira 43: 1525-1531.

Parker JE, Szabo V, Staskawicz BJ, Lister C, Dean C, Daniels MJ and Jones JDG (1993) Phenotypic characterization and molecular mapping of the Arabidopsis thaliana locus RPP5, determining disease resistance to Peronospora parasitica. The Plant Journal 4: 821-831.

Parlevliet JE (1997) Components of resistance that reduce the rate of epidemic development. Annual Review of Phytopathology 17: 203-222.

Santos JA, Juliatti FC, Santos VA, Polizel AC, Juliatti FC and Hamawaki OT (2007) Caracteres epidemiológicos e uso da análise de agrupamento para resistência parcial à ferrugem da soja. Pesquisa Agropecuária Brasileira 42: 443-447.

Schafer JF (1970) Tolerance to plant disease. Annual Review of Phytopathology 9: 235-252.

Yorinori JT, Utiamada CM, Sato LN, Mutta FTT and Roim FLB (2003) Perdas ocasionadas pela ferrugem da soja (Phakopsora pachyrhizi). Fitopatologia Brasileira 28: 210. 